\title{
In the Search for New Anticancer Drugs, IV+ Antitumor Activity of Seleno-TEPA
}

\author{
Maria Konieczny \\ Carl A. Olson Memorial Laboratories, Department of Chemistry, Rutgers University, \\ Newark, New Jersey 07102, U.S.A. \\ Peter L. Gutierrez* \\ Developmental Therapeutics, University of Maryland Cancer Center, 655 W. \\ Baltimore Street, Baltimore, Maryland 21201, U.S.A.
}

George Sosnovsky

Department of Chemistry, University of Wisconsin-Milwaukee, Milwaukee, Wisconsin 53201, U.S.A.

Z. Naturforsch. 38b, 1138-1141 (1983); received August 30, 1982/March 14, 1983

Thio-TEPA, Selenium, Seleno-TEPA, Anticancer Drugs

In order to test the effect of selenium on the anticancer activity of alkylating drugs, Seleno-TEPA (4), the selenium analog of the clinically used Thio-TEPA (1) was tested in vivo against the lymphocytic P 388 and lymphoid L 1210 murine leukemias. Compound 4 is more active against $\mathrm{P} 388$ leukemia than against $\mathrm{L} 1210$, and appears to be active over a narrower concentration range than Thio-TEPA (1). Compound $\mathbf{4}$ is less active against $\mathrm{P} 388$ leukemia than 1, as evidenced by the T/C values of 164 for 4 and 239 for 1 at a dose of $4.2 \mathrm{mg} / \mathrm{kg}$. The activity of 4 was also evaluated on the HL 60 and K 562 human cell lines. Under the conditions of the cell colony assay technique, Seleno-TEPA (4) is less effective than Thio-TEPA (1).

\section{Introduction}

Recently, we compared $[1,2]$ the antitumor activity of Thio-TEPA (1) with two spin labeled analogs, SL-O-TT (2) and SL-NH-TT (3) [3].

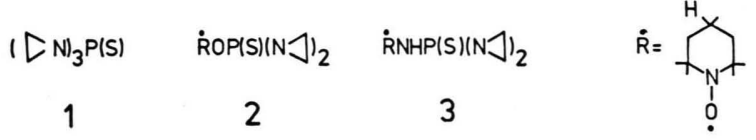

We have found [2] that the dose required for similar $\mathrm{T} / \mathrm{C}$ [4] values for the drugs studied in vivo against lymphocytic P 388 murine leukemia is in the following order $3>\mathbf{2}>\mathbf{1}$.

As an extension of these studies, we wish to report the effect of replacement of the sulfur moiety in Thio-TEPA (1) by a selenium moiety.

Selenium in trace quantities is an essential nutrient, and a natural antioxidant [5]. Selenium compounds have been shown to inhibit and/or prevent tumor growth. Thus, the incidence of chemically induced liver and colon cancers in mice is markedly

+ Part III: G. Sosnovsky and Y. Lukszo, Z. Naturforsch. 38b, 884 (1983).

* Reprint requests to Dr. Peter L. Gutierrez. 0340-5087/83/0900-1138/\$ 01.00/0 reduced on inclusion of selenium in animals' diet [6-9]. In humans, there are much lower death rates from cancer of digestive organs among people living in areas with relatively high concentration of selenium in the soil $[10,11,12]$.

Therefore, it was compelling for us to develop a potential anticancer agent containing selenium. The selenium analog of $\mathbf{1}$, i.e., the Seleno-TEPA (4) was prepared as described previously [13] by the oxidation of the corresponding trivalent tris-aziridine compound with selenium. Compound 5, which has no obvious alkylating capability, was synthesized in order to assess the possible activity and toxicity on the part of the selenium moiety.

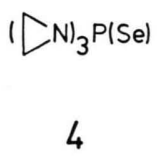<smiles>CN(C)[AsH2]</smiles>

\section{5}

Compounds $\mathbf{4}$ and $\mathbf{5}$ were evaluated in vivo against the lymphocytic P 388 and lymphoid L 1210 murine leukemias, and the results compared with those of Thio-TEPA (1). In addition, the activity of 4 was evaluated in vitro against HL 60 and K 562 human cell lines, and compared to Thio-TEPA. 


\section{Materials and Methods}

Pure Thio-TEPA (1) was obtained from Lederle Laboratories (Pearl River, New York) and used without purification. The synthesis of Seleno-TEPA (4) was described previously [13].

\section{Preparation of hexamethylselenophosphoramide (5)}

To a solution of hexamethylphosphorous triamide $(1.63 \mathrm{~g}, 10 \mathrm{mmol})$ in benzene $(25 \mathrm{ml})$ was added selenium $(2.0 \mathrm{~g}, 25 \mathrm{mmol})$. The mixture was stirred at room temperature for $20 \mathrm{~h}$, then filtered to remove the unreacted selenium. Concentration of the filtrate on a rotating evaporator at $20^{\circ} \mathrm{C}$ / 10-15 torr gave a white solid (2.45 g) which was purified by column chromatography on adsorption alumina, with dichloromethane as the eluant. Removal of the solvent under reduced pressure afforded pure $5(2.40 \mathrm{~g}, 99 \%)$, a white crystalline material, m.p. $47-47.5^{\circ} \mathrm{C}$.

$$
\begin{aligned}
& \mathrm{C}_{6} \mathrm{H}_{18} \mathrm{~N}_{3} \mathrm{PSe} \text { (242.16) } \\
& \text { Calcd C 29.73 H 7.49 N 17.42, } \\
& \text { Found C } 29.70 \text { H 7.66 N 17.17. } \\
& \text { M.S.: } m / e=241\left(\mathrm{M}^{+}, \mathrm{Se}^{78}\right), 242\left(\mathrm{M}^{+}+1\right) \text {, } \\
& 243\left(\mathrm{M}^{+}+2, \mathrm{Se}^{80}\right) \text {. }
\end{aligned}
$$

The in vivo antitumor activity was evaluated against lymphocytic P 388 and lymphoid L1210 murine leukemias following the protocols of the National Cancer Institute [4]. Approximately $10^{5}$ cells were injected i.p. into $\mathrm{CDF}_{1}\left(\mathrm{CD}_{2} \mathrm{~F}_{1}\right)$ mice at day 0 of the experiment ( 6 mice/group). Since 1, 4 , and $\mathbf{5}$ are water soluble, the compounds were injected as saline solutions. Control animals consisted of mice which were inoculated with tumor cells but not treated with the test compounds and of healthy mice which were injected daily for 10 days with saline. At day 1, i.p. injections of test compounds began $(0.005 \mathrm{ml} / \mathrm{g}$ weight $)$ and continued for 10 days. The animals were then observed for 30 days keeping a record of deaths and survivors. Data were analyzed by the $\mathrm{T} / \mathrm{C}$ method [4] where $\mathrm{T}$ represents the mean survival time of the treated group, and $\mathrm{C}$ the mean survival time of the tumor bearing control group. The percent of increase in life span (\% ILS) parameter was evaluated by the formula $[(\mathrm{T}-\mathrm{C}) / \mathrm{C}] \times 100$. HL 60 cells were maintained in continuous liquid suspension culture [14]. The initial cell concentration was $2.5 \times 10^{5}$ cells/ml in RPMI (Roswell Park Memorial Institute) 1640 medium also containing $20 \%$ heat inactivated fetal calf serum (FCS), $0.3 \mathrm{mg} / \mathrm{ml} \mathrm{L}$-glutamine, $50 \mathrm{I} . \mathrm{U} . / \mathrm{ml}$ penicillin, and $5 \mu \mathrm{g} / \mathrm{ml}$ streptomycin. Unless stated otherwise, the HL 60 cell cultures were derived from cells cryopreserved after the 71st passage. Under these conditions, the cells had a population doubling time of approximately $48 \mathrm{~h}$. The K 562 cells [15] were maintained in continuous liquid suspension culture. The initial cell concentration was $2.5 \times 10^{4}$ cells $/ \mathrm{ml}$ in RPMI 1640 medium also containing $10 \%$ heat inactivated FCS, $0.3 \mathrm{mg} / \mathrm{ml}$ L-glutamine, $50 \mathrm{I} . \mathrm{U} . / \mathrm{ml}$ penicillin, and $50 \mu \mathrm{g} / \mathrm{ml}$ streptomycin. Under these conditions, the cells had a population doubling time of approximately $24 \mathrm{~h}$. HL 60 and K 562 cells clone spontaneously in soft agar at $10-22 \%$ and $20-50 \%$ efficiency, respectively. The test compounds were evaluated against HL 60 and K 562 cells by incubating $5 \times 10^{3}$ cells $/ \mathrm{ml}$ for 14 days in $35 \mathrm{~mm}$ Petri dishes at $37{ }^{\circ} \mathrm{C}, 100 \%$ humidity, and $7.5 \% \mathrm{CO}_{2}$ in the above medium, also containing $0.3 \%$ agar and the appropriate concentration of the test compound. After 14 days, colonies containing more than 50 cells were counted using a $20 \times$ dissecting microscope.

\section{Results and Discussion}

The results of the in vivo studies of compounds 1, 4, and 5 with P388 and L 1210 inoculated mice are shown in Table I. Compound 4 appears to be more active against P388 leukemia than against L 1210 leukemia. Thus, against L 1210, the maximum $\mathrm{T} / \mathrm{C}$ value, obtained at a dose of $5.7 \mathrm{mg} / \mathrm{kg}$, is only 117 , i.e., below the value of 125 which is required by the NCI protocol as the minimum T/C value for a drug to be considered as active, whereas against $\mathrm{P} 388$, the maximum $\mathrm{T} / \mathrm{C}$ value is 164 , obtained at the dose of $4.2 \mathrm{mg} / \mathrm{kg}$. For the same system, in the case of Thio-TEPA (1), the maximum $\mathrm{T} / \mathrm{C}$ value is much larger, i.e., 253 , obtained at the concentration of $5.7 \mathrm{mg} / \mathrm{kg}$. Although the doses for achieving maximum activity $(\mathrm{T} / \mathrm{C})$ for $\mathbf{1}$ and $\mathbf{4}$ are quite similar, i.e., only approximately $20 \%$ different, the magnitude of both the T/C and the \% ILS is different for the two drugs. Thus, at a maximum $\mathrm{T} / \mathrm{C}$, the increase in life span for Thio-TEPA (1) treated animals is $153 \%$, whereas for the SelenoTEPA (4) treated mice, it is only $64 \%$. Compound 4 appears to be active over a narrower concentration range as compared to Thio-TEPA. Thus, the therapeutic index for 4 is approximately 1.4, i.e., onehalf of the 2.75 value obtained for 1 [2]. Compound 5 appears to be inactive and nontoxic even at higher doses than those used in the case of 4.

Compound 4 was tested on two human cell lines, HL 60 and K 562. The HL 60 cell line is derived from peripheral blood leukocytes of a patient with acute progranulocytic leukemia [14]. The K 562 cell is derived from the pleural fiuid of a patient with chronic myelogenous leukemia in blast crisis [15]. These cells were incubated in the presence of Seleno-TEPA (4) and Thio-TEPA (1) in various concentrations. The results of the experiments are shown in Table II. Seleno-TEPA (4) 
Table I. Survival of P 388 and L 1210 Inoculated Mice Treated with Thio-TEPA (1), Seleno-TEPA (4), and Hexamethylselenophosphoramide (5).

\begin{tabular}{|c|c|c|c|c|c|}
\hline $\begin{array}{l}\text { Com- } \\
\text { pound }\end{array}$ & Tumor & $\begin{array}{l}\text { Dose } \\
{[\mathrm{mg} / \mathrm{kg}]}\end{array}$ & $\begin{array}{l}\text { Molarity } \\
{[\mathrm{mM}]}\end{array}$ & $\begin{array}{l}\text { Mean } \\
\text { survival } \\
\text { time } \\
\mathrm{T} / \mathrm{C}[\%]\end{array}$ & $\begin{array}{l}\text { ILS } \\
{[\%]}\end{array}$ \\
\hline 1 & P 388 & $\begin{array}{l}7.6 \\
5.7 \\
4.2 \\
3.2 \\
1.8 \\
1.8 \\
0.6\end{array}$ & $\begin{array}{l}8.0 \\
6.0 \\
4.5 \\
3.4 \\
1.9 \\
1.0 \\
0.6\end{array}$ & $\begin{array}{r}91 \\
253 \\
239 \\
213 \\
125 \\
118 \\
113\end{array}$ & $\begin{array}{r}8 \\
-\quad 83 \\
139 \\
113 \\
25 \\
18 \\
13\end{array}$ \\
\hline 4 & P 388 & $\begin{array}{r}13.4 \\
10.1 \\
7.6 \\
5.7 \\
4.2 \\
3.2 \\
1.8 \\
1.0 \\
0.6\end{array}$ & $\begin{array}{r}11.4 \\
8.5 \\
6.4 \\
4.8 \\
3.6 \\
2.7 \\
1.5 \\
0.8 \\
0.5\end{array}$ & $\begin{array}{r}0 \\
42 \\
50 \\
155 \\
164 \\
153 \\
96 \\
85 \\
87\end{array}$ & $\begin{array}{r}100 \\
-\quad 57 \\
-\quad 50 \\
55 \\
64 \\
-\quad 54 \\
-\quad 15 \\
-\quad 13\end{array}$ \\
\hline 4 & L 1210 & $\begin{array}{r}13.4 \\
10.1 \\
7.6 \\
5.7 \\
4.2 \\
3.2 \\
1.8 \\
1.0 \\
0.6\end{array}$ & $\begin{array}{r}11.4 \\
8.5 \\
6.4 \\
4.8 \\
3.6 \\
2.7 \\
1.5 \\
0.8 \\
0.5\end{array}$ & $\begin{array}{r}0 \\
54 \\
73 \\
117 \\
101 \\
68 \\
75 \\
68 \\
63\end{array}$ & $\begin{array}{r}-100 \\
-\quad 46 \\
-\quad 26 \\
17 \\
-\quad 1 \\
-\quad 32 \\
-\quad 25 \\
-\quad 32 \\
-\quad 37\end{array}$ \\
\hline 5 & P 388 & $\begin{array}{r}107.4 \\
53.7 \\
26.8 \\
13.4 \\
6.7\end{array}$ & $\begin{array}{r}88.7 \\
44.4 \\
22.2 \\
11.1 \\
5.6\end{array}$ & $\begin{array}{r}44 \\
97 \\
98 \\
96 \\
100\end{array}$ & $\begin{array}{r}-56 \\
-\quad 3 \\
-\quad 2 \\
-\quad 4 \\
0\end{array}$ \\
\hline 5 & L 1210 & $\begin{array}{r}107.4 \\
53.7 \\
26.8 \\
13.4 \\
6.7\end{array}$ & $\begin{array}{r}88.7 \\
44.4 \\
22.2 \\
11.1 \\
5.6\end{array}$ & $\begin{array}{r}57 \\
101 \\
106 \\
93 \\
93\end{array}$ & $\begin{array}{r}43 \\
1 \\
-\quad 6 \\
-\quad 7\end{array}$ \\
\hline
\end{tabular}

appears to be more active against HL 60 than against $\mathrm{K} 562$. Thus, against HL $60,50 \%$ inhibition of colony formation is achieved at a concentration of approximately $6 \times 10^{-7} \mathrm{M}$, while against $\mathrm{K} 562$, similar inhibition is achieved at the higher dose of approximately $2 \times 10^{-6} \mathrm{M}$. Thio-TEPA (1) is more effective against HL 60 than Seleno-TEPA, as evidenced by the result that $50 \%$ inhibition of colony growth is achieved at a dose of $2 \times 10^{-7} \mathrm{M}$ concentration of 1 , and $6 \times 10^{-7} \mathrm{M}$ concentration of 4 . It appears that compounds 1 and $\mathbf{4}$ interact analogously with the tumor cells, as can be seen from the plot of the log of the percent colonies as a function of drug concentration (Figure 1).
Table II. Survival of human cell colonies in the presence of Thio-TEPA (1) and Seleno-TEPA (4).

\begin{tabular}{|c|c|c|c|c|}
\hline $\begin{array}{l}\text { Cell } \\
\text { line }\end{array}$ & $\begin{array}{l}\text { Com- } \\
\text { pound }\end{array}$ & $\begin{array}{l}\text { Concentration } \\
\text { (M) }\end{array}$ & $\begin{array}{l}\text { Colonies } \\
\text { formed }\end{array}$ & $\begin{array}{l}\% \\
\text { Survivors }\end{array}$ \\
\hline \multirow[t]{7}{*}{ HL 60} & 1 & 0 & $699+29$ & 100 \\
\hline & & $1 \times 10^{-7}$ & $405 \pm 36$ & 58 \\
\hline & & $2 \times 10^{-7}$ & $351 \pm 30$ & 50 \\
\hline & & $4 \times 10^{-7}$ & $279 \pm 36$ & 40 \\
\hline & & $6 \times 10^{-7}$ & $158 \pm 19$ & 23 \\
\hline & & $8 \times 10^{-7}$ & $81+14$ & 12 \\
\hline & & $1 \times 10^{-6}$ & $75 \pm 13$ & 11 \\
\hline \multirow[t]{8}{*}{ K 562} & 4 & 0 & $459 \pm 27$ & 100 \\
\hline & & $1 \times 10^{-7}$ & $430 \pm 16$ & 93 \\
\hline & & $6 \times 10^{-7}$ & $404 \pm 19$ & 87 \\
\hline & & $8 \times 10^{-7}$ & $348 \pm 6$ & 75 \\
\hline & & $1 \times 10^{-6}$ & $274 \pm 85$ & 59 \\
\hline & & $2 \times 10^{-6}$ & $211 \pm 87$ & 45 \\
\hline & & $4 \times 10^{-6}$ & $0 \pm 0$ & 0 \\
\hline & & $6 \times 10^{-6}$ & $0 \pm 0$ & 0 \\
\hline \multirow[t]{7}{*}{ HL 60} & 4 & 0 & $1172 \pm 41$ & 100 \\
\hline & & $1 \times 10^{-7}$ & $1048 \mp 43$ & 93 \\
\hline & & $2 \times 10^{-7}$ & $836 \pm 19$ & 71 \\
\hline & & $4 \times 10^{-7}$ & $720 \pm 21$ & 61 \\
\hline & & $6 \times 10^{-7}$ & $562 \pm 33$ & 48 \\
\hline & & $8 \times 10^{-7}$ & $562 \pm 57$ & 48 \\
\hline & & $1 \times 10^{-6}$ & $28 \pm 4$ & 2 \\
\hline
\end{tabular}

In conclusion, unlike Thio-TEPA (1) which is equally effective [16] against P 388 and L 1210 leukemias in vivo the Seleno-TEPA (4) is active only against P 388. Although the replacement of the sulfur moiety in $\mathbf{1}$ with selenium affords a compound less active than the clinically used drug 1 , the apparent reduced toxicity of Seleno-TEPA (4) as compared to $\mathbf{1}$ could be an important consideration in the designing of anticancer drugs.

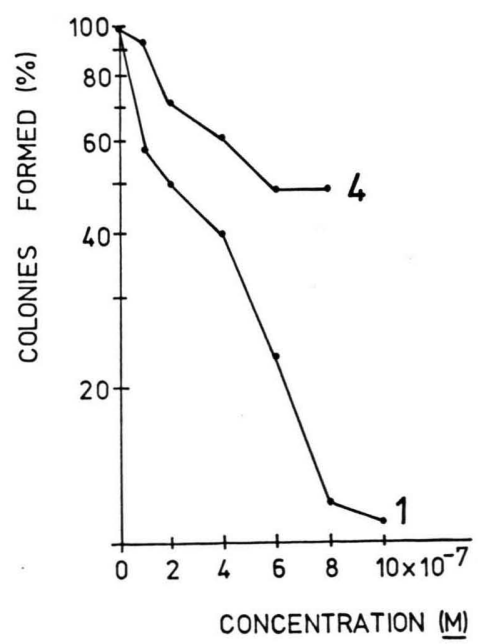

Fig. 1. HL 60 cells incubated with Thio-TEPA (1) and Seleno-TEPA (4). 
This work was supported in part (G. S.) by the National Foundation for Cancer Research, and in part (P. L. G.) by the Bressler Foundation, Uni- versity of Maryland Medical School. One of us (P. L. G.) would also like to thank Mr. Scott Rifkin for technical assistance.
[1] M. Konieczny, G. Sosnovsky, and P. Gutierrez, Z. Naturforsch. 36 b, 888 (1981).

[2] P. Gutierrez, M. Konieczny, and G. Sosnovsky, Z. Naturforsch. 36 b, 1612 (1981).

[3] A. B. Shapiro, A. A. Kropacheva, V. I. Suskina, B. V. Rozynov, and E. G. Rozantsev, Izv. Akad. Nauk SSSR, Ser. Khim. 1971, 864.

[4] R. Geran, N. Greenberg, M. Macdonald, A. Schumacher, and B. Abbott, Cancer Chemother. Rep. Part 3 3(2), 1 (1972).

[5] R. J. Shamberger, M. G. Simic and M. Karel (eds): Autoxidation in Food and Biological Systems, Plenum Press, New York 1980, p. 639.

[6] C. C. Clayton and C. A. Baumann, Cancer Res. 9, 575 (1949).

[7] M. M. Jacobs, B. Jansson, and A. C. Griffin, Cancer Lett. 2, 133 (1977).
[8] M. V. Marshall, M. M. Jacobs, and A. C. Griffin, Proc. Am. Assoc. Cancer Res. 19, 75 (1978).

[9] G. N. Schrauzer and D. Ishmael, Ann. Clin. Lab. Sci. 4, 441 (1974).

[10] R. J. Shamberger and C. E. Willis, C. R. C. Crit. Rev. Clin. Lab. Sci. 2, 221 (1971).

[11] R. J. Shamberger, S. A. Tytko, and C. E. Willis, Arch. Environ. Health 31, 235 (1976).

[12] G. N. Schrauzer, D. A. White, and C. J. Schneider, Bioinorganic Chem. 7, 23 (1977).

[13] G. Sosnovsky and M. Konieczny, Synthesis 1978, 583.

[14] S. J. Collins, R. C. Gallo, and R. E. Gallagher, Nature 270, 347 (1977).

[15] C. B. Lozzio and B. B. Lozzio, Blood 45, 32 (1975).

[16] H. B. Wood in J. F. Saunders and S. K. Carter (eds): Methods of Development of New Anticancer Drugs, U.S. Government Printing Office, Washington, D.C., 1977, p. 15. 